\title{
BEHAVIOUR GHANGE
}

1985 VOLUME 2 ISSUE No. 2

\section{Articles}

\section{Mini-series on Schizophrenia \\ Guest Editors: Henry Jackson \& Nirbhay Singh}

Henry J. Jackson and Nirbhay Singh

I. Harry Minas, Henry Jackson, Peter Doherty and Pat McGorry Janine E. Watson and Nirbhay N. Singh

Mark Dadds, Roger Dooley and Ken Pakenham

Robin C. Winkler

Paul R. Martin Ann Bissett, Kenneth R. Mitchell and Gabor Major

Alan Hudson, Jenny Vincent, Ray Wilks and Ronald Drabman

Caroline Mohr and Christopher F. Sharpley

Geoffrey N. Molloy

Donald A. Sanford and Rob H. Elzinga

Barry Parsonson and John F. Smith
78-79 Introduction to mini-series on schizophrenia.

80-93 Schizophrenia: An overview.

94-101 Social skills training for schizophrenic patients.

102-110 Behavioural family interventions in the management of schizophrenia: A review.

111-118 Twenty years of token economies in psychiatric institutions: Some basic issues.

119-128 Trends in behaviour therapy: Progression or regression?

129-135 The cervico-brachial pain syndrome: Muscle activity and pain relief.

136-142 "Beat the buzzer" for early morning dawdling: Two case illustrations.

143-147 Elimination of self-injurious behaviour in an autistic child by use of overcorrection.

148-150 Two factors are too simplistic: A response to Birnbrauer (1985).

151-152 A case of misperception: Comment on Smith, Henriques and Parsonson (1985).

153-154 A case of misperception by Sandford and Elzinga.

\section{Book reviews}




\title{
AUSTRALIAN BEHAVIOUR MODIFICATION ASSOCIATION
}

\begin{abstract}
AIMS
The Australian Behaviour Modification Association (ABMA) is a multidisciplinary professional society. The aims of the Association are:

(a) To organise continuing education and training in the principles and practice of behaviour modification;

(b) To publish and disseminate information to members about developments in behaviour modification in Australia and other countries;

(c) To educate the community in the principles and ethical practice of behaviour modification;

(d) To liaise and consult with other persons or organisations in the teaching and practice of behaviour modification;

(e) To promote the ethical practice of behaviour modification by members;

(f) To organise or assist in the organisation of an annual National Conference on Behaviour Modification.
\end{abstract}

\section{NATIONAL AND BRANCH PRESIDENTS}

\author{
NATIONAL PRESIDENT \\ Alan Hudson \\ Department of Psychology \\ Phillip Institute of Technology \\ Plenty Road, \\ Bundoora, Vic 3083 \\ Tel: (03) $468^{\prime} 2200$
}

\section{BRANCH PRESIDENTS}

ILLAWARRA BRANCH

Danny Taylor

Kemble House,

34 Kemble Street,

Wollongong, NSW 2500

Tel: (042) 283588

QUEENSLAND BRANCH

Mark Dadds

Department of Psychology

University of Queensland

St. Lucia, Qld 4067

Tel: (07) 3774034

VICTORIAN BRANCH

Alan Hudson

Department of Psychology

Phillip Insitute of Technology

Plenty Road,

Bundoora, Vic. 3083

Tel: (03) 4682200
SYDNEY BRANCH

Agnes Rappaport

Department of Psychology,

University of Sydney,

NSW 2006

Tel: (02) 4672857

\section{SOUTH AUSTRALIAN BRANCH \\ Don Tustin}

Psychology, Minda Incorporation

King George Avenue,

Brighton, S.A. 5048

Tel: (08) 2964711

\section{WESTERN AUSTRALIAN BRANCH \\ Paul Martin \\ Clinical Unit \\ Department of Psychology}

The University of Western Australia

Nedlands, W.A. 6009

Tel: (09) 3802644

Behaviour Change is published twice-yearly by ABMA. The theme of the journal is applied behavioural psychology. Behaviour Change is indexed in the following information systems. Australian Education Index, Behavioural Abstracts, Excerpta Medica, Psychological Abstracts. 


\title{
BEHAVIOUR CHANGE
}

\author{
EDITOR \\ Neville King \\ Phillip Insitute of Technology, Vic. \\ PRODUCTION EDITOR \\ Henry Jackson \\ Royal Park Psychiatric Hospital \\ Health Commission, Vic \\ BOOK REVIEW EDITOR \\ Gregory Murphy \\ Phillip Institute of Technology, Vic.
}

\author{
MANAGING EDITOR \\ Andrew Remenyi \\ Lincoln Institute of Health Sciences, Vic.
}

Jay Birnbrauer

Murdoch University, W.A.

Mark Dadds

University of Queensland

Tony Floria

Macquarie Hospital, North Ryde

Stan Ginsberg

University of Wollongong, NSW

Ten Glynn

University of Otago, N.Z.

Charles Hart

Flinders University
ASSOCIATE EDITORS

David Horne

University of Melbourne

Chris Williams

University of Tasmania

Paul Martin

University of Western Australia

Ken Mitchell

University of Newcastle

Iain Montgomery

University of Tasmania

Barry Parsonson

University of Waikato
Neville Owen

University of Adelaide

Matt Sanders

University of Queensland

Chris Sharpley

Monash University

Nirbhay Singh

University of Canterbury, N.Z.

Peter Wilson

University of Sydney

John Smith

University of Waikato

\section{INTERNATIONAL CONSULTANTS}

Jack Annon

University of Hawaii

Donald Baer

University of Kansas

Albert Bandura

Stanford University

David Barlow

State University of New York at Albany

Wesley Becker

University of Oregon

Alan Bellack

Medical College of Pennsylvania

Nigel Blagg

Education Department, Somerset, England

Edward Blanchard

State University of New York at Albany

Rex Forehand

University of Georgia
Richard Foxx

Southern Illinois University

Cyril Franks

Rutgers University

Martin Herbert

The University, Leceister

Alan Kazdin

University of Pittsburgh

Steven Linton

Orebro Medical Centre Hospital, Sweden

Alan Marlatt

University of Washington

K. Daniel O'Leary

State University of New York at Stony Brook

Thomas Ollendick

Virginia Polytechnic Institute \& State University

Rodrigue Otis

Universite de Sherbrooke, Quebec
A. Desmond Poole

The Queen's University of Belfast

Stanley Rachman

University of British Columbia

Alan Ross

State University of New York at Stony Brook

Robert Weiss

University of Oregon

Keith Wheldall

University of Birmingham

Terry Wilson

Rutgers University

Joseph Wolpe

Temple University Medical School

Michel Hersen

University of Pittsburgh

Judy Hutching

Bangor, Wales 